\title{
A Review of Teaching Adults: A Practical Guide for New Teachers, by Ralph G. Brockett
}

\author{
Mohammad Omar Shiddike \\ University of Regina
}

Teaching Adults: A Practical Guide for New Teachers is an essential book for beginning teachers in adult education. In Part I, "Getting Started," Brockett presents a comprehensive discussion of the pedagogical themes related to teaching adult students. He emphasizes that adult teaching methods differ greatly from teaching other learners. A key tenet of adult education is that teachers must carefully consider the age and learning ability of their students. Adult learners have a lot of life experience, and they learn from the real world too, which helps them to progress more quickly than young learners. Because of this, Brockett indicates that adult education requires a combination of formal and informal class and training settings, and teachers need very strong pedagogical knowledge in order to educate adult students effectively. Brockett believes that "effective teaching leads to successful learning” (p. 9). He also defines "a teacher in seven words": trust, empathy, authenticity, confidence, humility, enthusiasm, and respect. Teachers should develop these qualities throughout their teaching practice. However, Brockett cautions that these qualities alone are not enough to ensure successful teaching for adult learners.

In Part II, Brockett explores four keys to effective teaching: know the content, know the adult learner, know teaching, and know yourself. Brockett focuses on the teacher as a learner who does not feel that he/she already knows everything. He does not believe that there is a time when learning ends and the educator is "just teaching." According to Brockett, teachers of adults need to maintain their relevance as teachers by continuing their learning through reading, writing, researching, professional engagements, attending professional conferences, and participating in a variety of social networking activities. Furthermore, they must then practice that knowledge in their own professional activities.

Next, Brockett offers many tips for understanding adult learners. He explains that most adults are actively involved in learning and undertake at least one learning project every year. Adults have the ability to learn successfully throughout their lives. Adult learners bring a wealth of experience to the teaching/learning setting and this experience can be a valuable resource. It is important to recognize that decisions teachers make about how they will teach are based on whether they are trying to change attitudes and values, build skills and performance, or impart knowledge and information. Most adult learning is self-directed. The need for adult learning is often triggered by some kind of developmental transition or crisis. Adults choose to learn for many different reasons, and teachers need to know what these are. It is important to understand how to use motivation strategies to help learners get excited about content and, in some cases, to help break down learner resistance. Teachers of adults need to understand the many kinds of barriers that can limit whether adults choose a learning activity, or stay with the activity. Most successful adult learning takes place in a collaborative or cooperative setting where sharing and synergy are crucial. The ultimate purpose of adult education is to help learners think for themselves.

Brockett explains two key concepts in adult education: andragogy (teaching adults) and self-directed learning. He outlines six valuable assumptions of andragogy, which are helpful for teachers when dealing with adults as potential learners. In Part II, Brockett includes six chapters where he shares his opinion about teacher preparation, understanding adult learners in order to 
teach them effectively, and six teaching techniques, all of which are essential for effective teaching in the classroom.

In Part III, Brockett focuses on the practical aspects of effective teaching. He begins this part by reflecting on the learning environment. He states that every environment has variables such as psychological, physical, and social factors that can influence learning. Brockett believes that classroom climate, arrangement of classroom, proper lighting, seating arrangement, comfortable seats, and classroom temperature also affect the learning environment. To help the reader understand his points, he provides a Table illustrating different seating arrangements along with positive and negative considerations. Brockett also discusses the social dimension of the learning environment. He considers five situations for "creating a safe space for learning, where all learners are valued and treated in an equitable manner" (p. 108). Brockett also considers the challenges of teaching in large vs. small classrooms, as well as using proper technological equipment such as multi-media projectors and visual equipment.

In Chapter 10, Brockett continues to explore strategies for recognizing and overcoming possible learning barriers. He discusses resistance he has encountered and reveals his personal strategies to avoid such resistance. This leads to the topic of motivation: how teachers can increase the motivational level of their learners. Brockett also mentions the learning model proposed by John Keller in 1983, which features attention, relevance, confidence, and satisfaction. This model outlines how teachers can draw learners' attention, demonstrate the topic is relevant to the learner, and help learners to gain confidence and a full sense of self-satisfaction. By focusing on these motivational dimensions, teachers may overcome student anxiety, help students gain confidence, avoid disruptive learning situations, handle cheating and plagiarism, and prepare all learners to be strong students.

In his epilogue, Brockett reviews the seven qualities of an effective teacher. Trust, empathy, authenticity, and respect are basic qualities that set the tone for the teacher-learner relationship. At this point, Brockett shares two credos he adopted when he first became involved in teaching adult learners: "Bringing out the best in my learners is what I strive to achieve. My other credo is...I would rather spend my time and effort building people up than tearing them down" (p. 147). Finally, Brockett mentions that being an effective teacher of adults means that teachers need to demonstrate the quality of caring. He believes that "a teacher who does not care about what he or she is teaching, or is unable to demonstrate this quality of caring, will be doomed to being, at best, a mediocre teacher" (p. 147-148).

Brockett divides readers into four categories: those who are new teachers; those who have responsibility for teaching adults but who don't think of themselves primarily as teachers; those who are experienced teachers, but may not be prepared to face the challenge of meeting the unique needs of adult learners; and finally, for those graduate students in adult education or related fields who are interested in learning about teaching adults. This book is an effective guide for those who see teaching as more than "just another profession."

Teaching means to care and build up the future generation. Though Brockett focuses on adult teaching, I believe that these qualities are actually necessary for every level of effective teaching. My understanding as a former teacher is that effective teaching is all about building the learners into strong citizens. Some researchers may criticize the book for lacking theoretical perspective, but Brockett states clearly that his intended audience is mainly new graduates who 
really want to participate in the teaching profession and want to teach effectively. I highly recommend this book to new educators engaged in teaching at any level of education and any institutional platform. I also feel it would be valuable for any teacher seeking to assess and improve their teaching and to further develop effective teaching strategies.

\section{Reference}

Brockett, R. G. (2015). Teaching adults: A practical guide for new teachers. San Francisco, CA: Jossey-Bass. 